\title{
FILM ANIMASI KAPTEN SAMADIKUN SEBAGAI PAHLAWAN SAMUDRA
}

\author{
Hilmy Fauzan, Azhari Amri \\ Desain Komunikasi Visual, Fakultas Bahasa dan Seni, Universitas Indraprasta PGRI
}

\begin{abstract}
Kapten Samadikun adalah seorang tokoh pahlawan Angkatan Laut Republik Indonesia (ALRI) yang mempertahankan harga diri bangsa dengan mengorbankan jiwa dan raganya sehingga beliau gugur dalam pertempuran laut di Cirebon dan mendapatkan gelar Pahlawan Samudra. Setelah menganalisis dan mendapatkan kesimpulan, maka diperlukan sebuah perancangan media film animasi Kapten Samadikun dengan memadukan beberapa elemen-elemen desain. Film animasi yang akan dirancang berjudul "Pahlawan Samudra Kapten Samadikun" hal ini didasari oleh perjuangan Kapten Samadikun sehingga diberikan gelar Pahlawan Samudra oleh pemerintah. Gaya ilustrasi yang diterapkan dalam film ini adalah anime, hal ini dilakukan karena anime adalah gaya ilustrasi yang sederhana dan dapat diterima oleh target khalayak yaitu remaja. Metode penelitian yang dilakukan adalah dengan menggunakan metode kualitatif yaitu dengan cara melakukan studi literatur, studi lapangan, kemudian dengan melakukan observasi dan melakukan wawancara kepada narasumber yang kompeten. Dengan adanya film animasi ini diharapkan para remaja mengenal sosok Kapten Samadikun dan dapat meneladani sifat-sifat nasionalisme dan patriotisme dari Kapten Samadikun.
\end{abstract}

Keywords: Animasi, Sejarah, Pahlawan, Samadikun,

\begin{abstract}
Captain Samadikun was a hero of the Angkatan Laut Republik Indonesia (ALRI) who defended the national self-esteem at the expense of his body and soul so he died in a naval battle in Cirebon and won the title of Hero of the Ocean. After analyzing and drawing conclusions, it is necessary to create an animation film of Captain Samadikun by combining several design elements. The animation film is titled "Hero of the Ocean Captain Samadikun". This was based on the struggle of Captain Samadikun so that he was given the title Ocean Hero by the government. The illustration style applied in this film is anime, because it is a simple illustration style and can be accepted by the target audience which is teenagers. The research method used is to use qualitative methods by conducting literature studies, field studies by conducting observations and interviews with competent interviewees. Through this animatio film it is expected that teenagers know the figure of Captain Samadikun and be able to emulate the characteristics of nationalism and patriotism as well as he has.
\end{abstract}

Keywords: Animation, History, Heroes, Samadikun

Correspondence author: Hilmy Fauzan, hilmyfauzan16@gmail.com, Depok, Indonesia

This work is licensed under a CC-BY-NC 


\section{Pendahuluan}

Nama Kapten Samadikun dikenal setelah terjadinya peristiwa pertempuran di Laut Jawa tepatnya di perairan Cirebon pada tanggal 5 Januari 1947. Dalam pertempuran tersebut Kapten (Anumerta) Samadikun telah memberikan perlawanan secara heroik dengan tidak memperhitungkan untung rugi bagi dirinya yang terbukti bahwa ia dengan rela telah mengorbankan jiwa raganya gugur dan tenggelam bersama kapal.

Pertempuran laut di Cirebon pada tanggal 5 Januari 1947 mempunyai latar belakang yang kompleks dan tidak hanya disebabkan oleh ketidaksenangan Belanda atas latihan perang Angkatan Laut Republik Indonesia (ALRI) Cirebon yang dianggapnya melanggar status quo. Tindakan Belanda menyerang Pelabuhan Cirebon secara langsung tentu akan mendatangkan reaksi dan kecaman internasional. Untuk itu, Belanda berusaha mencari pembenaran atas serangannya dengan mengatakan bahwa Indonesia melanggar status quo yang tercipta melalui Perundingan Linggarjati (Dahuri et al. 87).

Dalam usaha meningkatkan kewaspadaan dan keterampilan pasukan, di Cirebon ALRI mengadakan latihan gabungan yang terdiri dari unsur Angkatan Darat dan Armada Pangkalan III Cirebon dari tanggal 1 sampai dengan tanggal 5 Januari 1947. Selama latihan berlangsung kapal perang Belanda melakukan pengintaian dari jauh. Pada hari latihan terakhir kapal-kapal Angkatan Laut menuju ke utara dalam formasi iringan. Dalam perjalanan itu mereka bertemu dengan kapal perang Belanda, yang kemudian memberi isyarat memerintahkan supaya kapalkapal Republik Indonesia tersebut berhenti (Sudharmono 135).

Letnan I Samadikun mengabaikan isyarat dari Belanda dan Letnan I Samadikun mengeluarkan perintah agar kapal-kapal eskader selain kapal Gajah Mada masuk ke pelabuhan, untuk menyelamatkan anak buah dan kapal dari serangan musuh. Perintah itu didasarkan pada perhitungan bahwa melakukan serangan bersama tidak mungkin karena melihat kemampuan persenjataan dan kecanggihan kapal Belanda yang jauh lebih baik (Sanna 31).

Kemudian kapal Belanda mulai melakukan tembakan terhadap kapal Gajah Mada, tidak terima karena dianggap melakukan pelanggaran di wilayah teritorial Indonesia Letnan I Samadikun melakukan manuver terhadap kapal Belanda dengan melakukan serangan balik meskipun tidak seimbang Letnan I Samadikun tetap tidak ingin harga diri bangsa dan negara Indonesia diinjak-injak. Tembakan kapal Belanda membuat kapal Gajah Mada terbakar sehingga membuat para awak kapal Gajah Mada mencoba menyelamatkan diri dengan menceburkan diri ke laut. Letnan I Samadikun pada saat itu justru naik ke atas anjungan kapal dan melakukan serangan menggunakan mitraliyur 12,7 dengan tekad mempertahankan harga diri bangsa beliau menolak menyerah begitu saja hingga pada tembakan terakhir kapal Belanda mengenai kamar mesin kapal Gajah Mada, Letnan I Samadikun yang berada di atas anjungan terkena pecahan peluru hingga tangan kirinya putus dan tenggelam bersama kapal RI Gajah Mada (Sanna 33).

Berdasarkan hasil wawancara dengan Mustaqim Asteja sebagai Ketua Komunitas Sejarah dan Budaya Kendi Pertula Cirebon (26 Agustus 2018), disampaikan bahwa aksi heroisme Kapten (Anumerta) Samadikun patut diteladani oleh generasi muda. Kapten Samadikun patut dibanggakan dan menjadi contoh semangat nasionalisme dan tanggung jawabnya untuk mempertahankan harga diri bangsa perlu diapresiasi oleh kita. Tidak banyak masyarakat yang mengetahui bahwa di Cirebon pernah ada peristiwa pertempuran heroik, bahkan masyarakat Cirebon itu sendiri belum tentu mengetahuinya. Masyarakat tidak asing mendengar nama-nama pahlawan seperti Cut Nyak Dhien, Pangeran Diponegoro, Laksamana TNI R.E Martadinata dan lainnya, yang telah mendapat gelar pahlawan nasional tetapi tidak mengetahui tentang Kapten Samadikun. 
Dalam wawancara dengan Muhamad Mukhtar Zaedin sebagai sejarawan Cirebon (26 Agustus 2018) dapat disampaikan bahwa pada saat ini pengetahuan masyarakat tentang Kapten (Anumerta) Samadikun dan peristiwa pertempuran laut di Cirebon masih minim selain itu media yang menyampaikan informasi tentang Kapten Samadikun juga masih terbatas sehingga menjadi faktor kurang dikenalnya sosok Kapten Samadikun, oleh karena itu peneliti berkeinginan merancang sebuah media yang membahas tentang perjuangan Kapten Samadikun sebagai pahlawan samudra dalam pertempuran sengit di Cirebon.

Menurut Suryadi, dkk. (dalam Subaryana 26-27) telah terjadi penurunan sifat idealisme, nasionalisme dan patriotisme serta ketidakpastian masa depan pemuda. Dengan demikian patutlah kita meneladani sifat-sifat nasionalisme dari Kapten (Anumerta) Samadikun ia rela mengorbankan jiwa raganya secara heroik dan tidak mudah menyerah menghadapi musuh yang jelas terlihat lebih kuat. Sifat kepemimpinan dan tanggung jawab dari Kapten (Anumerta) Samadikun hingga rela mengorbankan dirinya sebagai umpan agar kapal-kapal Armada lainnya selamat patut kita teladani.

Terkait psikologi manusia, Rahman (238) menyatakan bahwa remaja dalam perkembangannya selalu membutuhkan seorang tokoh identifikasi. Identifikasi berarti dorongan untuk menjadi identik (sama) dengan orang lain. Dengan pernyataan ini maka diperlukan sebuah media untuk mengenalkan sifat-sifat heroisme Kapten Samadikun kepada remaja dan diharapkan Kapten Samadikun dapat menjadi tokoh identifikasi tersebut.

Berdasarkan penelusuran peneliti, pada saat ini hanya ada beberapa media cetak berupa buku yang membahas mengenai Kapten Samadikun. Salah satunya adalah buku yang berjudul "Pahlawan Samudera Kapten Samadikun". Belum ada yang memperkenalkan tokoh Kapten (Anumerta) Samadikun melalui media audio visual, oleh karena itu peneliti berharap ada sebuah media audio visual yang memperkenalkan Kapten Samadikun. Dengan adanya media audio visual diharapkan masyarakat dapat lebih mengenal karakter sosok heroik Kapten (Anumerta) Samadikun.

Berdasarkan penjelasan-penjelasan di atas, maka peneliti ingin merancang sebuah film animasi Kapten (Anumerta) Samadikun yang diharapkan dapat menjadi sosok identifikasi bagi masyarakat melalui film animasi yang akan peneliti rancang. Film animasi dipilih karena menurut (Munir 426) media animasi adalah perangkat yang superior dibandingkan ilustrasi statis untuk sebuah pembelajaran. Selain itu menurut Kemp dan Dayton (dalam Sukiyasa and Sukoco 129) media animasi memiliki manfaat dapat membangkitkan kemauan untuk bertindak dan meningkatkan sikap positif remaja dengan apa yang ia pelajari melalui animasi. Sehingga perancangan media tersebut sangat diperlukan guna menyampaikan informasi yang dapat diterima oleh para remaja. Dengan perancangan film animasi diharapkan dapat mengundang minat remaja agar dapat mengetahui adanya peristiwa pertempuran heroik kapal Gajah Mada dan dapat meneladani sifat-sifat patriotisme dan nasionalisme Kapten Samadikun. Oleh karena penelitian ini merupakan sebuah perancangan maka metode yang digunakan adalah metode kualitatif.

\section{Metode Penelitian}

Penelitian ini dilakukan sejak bulan Maret 2018 sampai dengan Agustus 2019. Proses penelitian meliputi, proses pengumpulan data, pengolahan data, dan perancangan. Tempat penelitian dilakukan di Jakarta dan Cirebon. Jenis penelitian yang dilakukan oleh peneliti dalam perancangan film animasi Kapten Samadikun sebagai Pahlawan Samudra adalah penelitian kualitatif. Menurut Saryono and Anggraeni (1), penelitian kualitatif merupakan penelitian yang 
digunakan untuk menyelidiki, menemukan, menggambarkan, dan menjelaskan kualitas atau keistimewaan dari pengaruh sosial yang tidak dapat dijelaskan, diukur atau digambarkan melalui pendekatan kuantitatif.

Dalam hal ini peneliti telah melakukan studi literatur, studi lapangan, observasi dan wawancara kepada narasumber yang kompeten. Kemudian seluruh data yang telah terkumpul dibahas lagi secara mendalam dan dari hasil pembahasan pada data tersebut peneliti akan menemukan kesimpulan menurut beberapa sumber data yang telah diteliti. Kumpulan data tersebut kemudian disusun menjadi sebuah karya penelitian yang berisi deskripsi dan gambar. Dalam metode observasi ini peneliti melakukan observasi di Pelabuhan Kota Cirebon untuk mendapatkan gambaran suasana sebelum pertempuran dan peneliti juga dapat melihat secara langsung benda-benda peninggalan Kapten Samadikun di antaranya adalah Pangkalan III ALRI Cirebon 1947 dan juga penemuan kapal RI Gajah Mada yang dapat peneliti amati melalui video dokumentasi yang diberikan oleh Pangkalan TNI-AL Cirebon. Untuk memperkuat data penelitian setelah melakukan studi pustaka dan observasi, metode wawancara menjadi data untuk melengkapi data agar menjadi valid. Wawancara ini dilakukan dengan bertanya langsung kepada orang yang dianggap mampu memberikan data maupun informasi secara rinci mengenai objek penelitian.

\section{Hasil dan Pembahasan}

\section{Tinjauan Animasi}

Menurut (Rochman et al. 5) animasi merupakan bayangan dari masa kecil kita akan impian tentang dunia fantasi yang seolah-olah semuanya hidup dan berada di sekeliling kita. Melalui imajinasi, kita dapat mewujudkannya dengan menggunakan benda-benda yang ada di sekeliling kita, seperti gambar, mainan, boneka, atau benda lainnya sehingga mereka seolaholah hidup di dunia yang kita ciptakan. Contohnya, anak-anak berimajinasi bahwa mainannya hidup dengan cara menggerak-gerakkan, melemparkan, atau mengajaknya berbicara.

Animasi ialah membuat ilusi gerakan dengan teknik memotret gambar atau posisi suatu objek. Efek visual dari animasi seperti sapuan (wipe), pemudaran (fade), zoom, dan dissolve yang tersedia pada beberapa authoring, dan beberapa di antaranya dapat digunakan dalam animasi primitif. Animasi merupakan objek yang bergerak melintasi atau bergerak ke dalam dan keluar pada tampilan layar. Contoh, bola dunia yang berputar, objek yang bergerak, dan lain sebagainya. Animasi merupakan sumber utama untuk aksi dinamis dalam presentasi multimedia (Arifin et al. 97).

Pelopor dunia animasi adalah Walt Disney dan Roy Disney. Pada tahun 1923 mereka membuat animasi fantasi disertai iringan musik dengan tokoh kartun seekor tikus bernama Mortimer, sebuah tokoh cikal bakal Mickey Mouse. Setelah sukses dalam menghidupkan Mickey Mouse mereka membuat animasi "White snow and seven dwarfs" dan berbagai animasi lainnya yang sukses sampai sekarang dinaungi oleh Pixar Animation. Animasi mampu menyampaikan suatu konsep yang kompleks menjadi menarik secara visual dan juga dinamik sehingga animasi terus berkembang hingga saat ini (Purnomo and Andreas 7).

Menurut (Rochman et al. 7) secara teknis pembuatannya, animasi digolongkan dalam:

1. Animasi tradisional, atau disebut animasi sel atau gambar tangan telah dilakukan sejak abad XX untuk menciptakan ilusi gerak. Gambar dari animator disalin atau difotokopi ke lembaran transparan yang disebut sel atau media seluloid kemudian difoto satu per satu bersama latar belakangnya untuk dijadikan film bergerak. 
2. Animasi gerak-henti (stop motion), digunakan untuk mendeskripsikan animasi yang terbuat dari tanah liat atau clay, plastik, atau material lainnya untuk memanipulasi objek nyata. Pembuatan ilusi gerak dengan memotret semua frame satu per satu dan kemudian menggabungkannya.

3. Animasi komputer, yang tergolong animasi ini adalah jika suatu karya dibuat secara digital melalui komputer. Sekarang ini, baik animasi dua dimensi maupun tiga dimensi sudah menggunakan komputer untuk menciptakan dunia animasinya.

Menurut (Syahfitri 215), animasi yang dulu memiliki prinsip sederhana sekarang telah berkembang menjadi beberapa jenis, yaitu:

1. Animasi 2D (Dua Dimensi)

Animasi ini biasa disebut dengan kartun. Kartun sendiri berasal dari kata cartoon yang memiliki arti gambar yang lucu.

2. Animasi 3D (Tiga Dimensi)

Animasi ini merupakan perkembangan dari animasi 2D, dengan animasi 3D gambar yang ditampilkan semakin hidup dan nyata mendekati aslinya.

3. Animasi Tanah Liat (Clay Animation)

Pada tahun 1897 animasi dapat digunakan dengan plasticin, yang memiliki bahan yang lentur seperti permen karet.

Dengan uraian tersebut, peneliti akan menggunakan teknik animasi komputer atau digital dengan jenis animasi 2D (dua dimensi) karena dalam perancangan animasi 2D dapat lebih menghemat waktu pengerjaan. Untuk membuat animasi 2D pasti diperlukan ilustrasi, oleh karena itu pertama, peneliti akan membuat ilustrasi manual yang kemudian discan atau difoto dan dipindahkan ke dalam komputer atau laptop kemudian dijadikan sebuah digital image yang siap digerakan menjadi animasi.

\section{Kapten (Anumerta) Samadikun}

Kapten (Anumerta) Samadikun lahir pada tanggal 8 Agustus 1923 di Matraman Gang II Jakarta dari seorang ibu bernama Kasinah dan ayah bernama R. Sukartin yang bekerja di Jawatan Kereta Api. Pada tahun 1927 Kapten Samadikun bersekolah di Frobel Neutrale School di Pasir Kaliki Bandung. Setelah dua tahun di Frobel Neutrale School (tahun 1927 dan 1928) beliau meneruskan pendidikannya di HIS (Hollandsch Inlandsche School) Bandung sampai di kelas 7, tahun 1936 orang tuanya pindah kembali ke Jakarta dan beliau menamatkan pendidikan HIS Baluel di Jakarta pada tahun 1937 (Dahuri et al. 102).

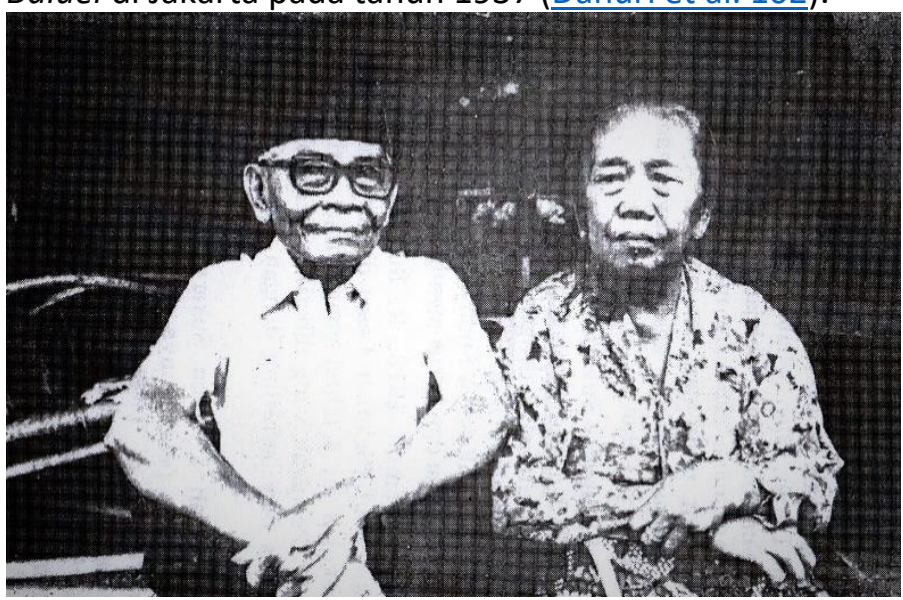

Gambar 1 Kedua orang tua Kapten (Anumerta) Samadikun Sumber: Sanna (4) 
Kapten (Anumerta) Samadikun meneruskan pendidikan ke MULO (Meer Uitgebreid Lager Onderwijs) di Manggarai lulus pada tahun 1940 dan meneruskan pendidikannya di AMS (Algemene Middelbare School). Pada tahun 1943 Pemerintah membuka Sekolah Pelayaran Tinggi (SPT) dan Sekolah Pelayaran Rendah (SPR) syarat untuk bersekolah di SPT dan SPR adalah pemuda-pemuda yang berijazah AMS dan MULO Kemudian Kapten (Aumerta) Samadikun mendaftarkan diri di SPT dan lulus pada tahun 1945 (Dahuri et al. 102).

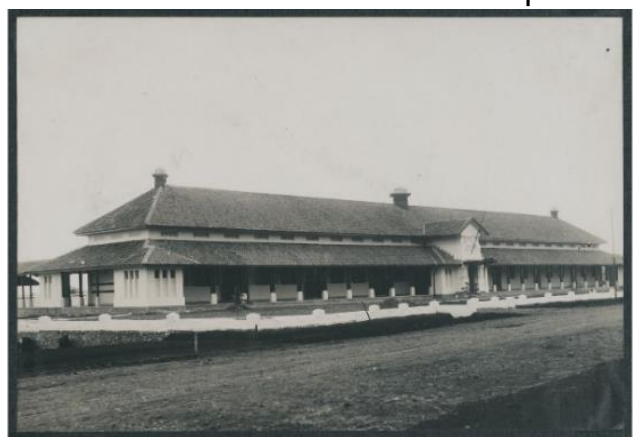

Gambar 2 Neutrale School dan HIS di Bandung Sumber: KITLV "Het Gebouw Van De Neutrale School Van De Bandoengsche Schoolvereniging Te Bandoeng"

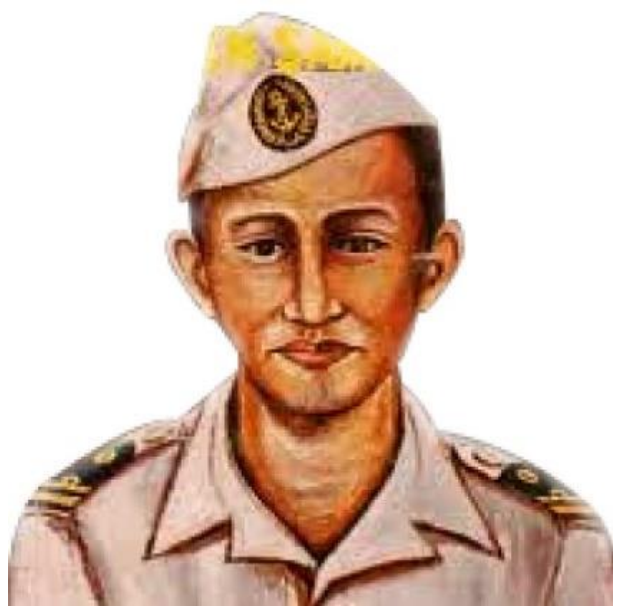

Gambar 4 Ilustrasi Kapten (Anumerta) Samadikun Sumber: Sanna (i)

Menurut Mustaqim Asteja, Kapten Samadikun adalah seseorang yang memiliki jiwa nasionalisme dan patriotisme yang tinggi. Hal tersebut ditunjukkan oleh aksi heroismenya melawan militer Belanda dengan mempertahankan kehormatan NKRI tanpa memikirkan keselamatan diri sendiri sampai akhirnya beliau gugur tenggelam bersama kapalnya.

Nilai-nilai patriotisme dan nasionalisme dari Kapten (Anumerta) Samadikun inilah yang harus dicontoh dan ditegakkan kembali untuk pemuda-pemudi saat ini, kisah pertempuran heroiknya patut dibanggakan bagi masyarakat Cirebon khususnya dan bagi masyarakat Indonesia pada umumnya. Berdasarkan penjelasan-penjelasan di atas, maka peneliti ingin merancang sebuah film animasi Kapten (Anumerta) Samadikun yang diharapkan dapat menjadi sosok identifikasi bagi masyarakat melalui film animasi yang akan peneliti rancang. 


\section{Konsep Dasar Perancangan}

Target yang diajukan oleh peneliti dalam perancangan film animasi ini yaitu remaja berusia 12 sampai dengan 15 tahun. Dengan remaja berstatus ekonomi kelas menengah ke atas. Remaja yang tinggal di perkotaan. Dengan berjenis kelamin laki-laki, berstatus pelajar SMP yang menyukai kegiatan menonton terutama menyukai film animasi yang diperankan oleh tokohtokoh pahlawan atau superhero dan ditujukan kepada remaja yang memiliki minat kepada sejarah bangsa Indonesia sehingga mereka akan dapat tertarik dengan film yang akan peneliti rancang. Target juga dapat mengenal sosok heroik Kapten Samadikun dan diharapkan mampu menumbuhkan karakter nasionalisme yang kuat pada remaja.

Perancangan media animasi ini berjudul Pahlawan Samudra Kapten Samadikun. Hal ini berdasarkan sifat-sifat heroik dan nasionalisme Kapten Samadikun sebagai komandan kapal RI Gajah Mada terutama pada saat bertempur di lautan melawan kapal perang Belanda pada tanggal 5 Januari 1947 yang menyebabkan gugurnya Kapten Samadikun dan 3 rekannya pada saat itu pangkat dari Kapten Samadikun adalah Letnan I Samadikun, kemudian setelah peristiwa tersebut pangkatnya dinaikan secara Anumerta menjadi Kapten (Laut) Samadikun dan diberikan penghargaan sebagai Pahlawan Samudra oleh pemerintah. Hal ini menunjukkan jiwa semangat juang yang tidak pernah kenal menyerah yang diharapkan dapat ditumbuhkan kepada khalayak. Film animasi yang akan dirancang oleh peneliti yaitu berjenis animasi 2 dimensi yang menggunakan wide size 16:9 (1920 × $1080 \mathrm{pxl})$ dengan format film mp4, dengan durasi waktu 8 menit 37 detik.

Moodboard sangat dibutuhkan dalam sebuah desain karena moodboard adalah media panduan desain. Tujuan dari moodboard adalah menentukan arah sebuah desain. Peneliti menerapkan 3 moodboard yang pertama adalah moodboard fashion yang akan menentukan pakaian dan atribut yang dikenakan oleh para tokoh dalam film animasi, kemudian moodboard karakter yang akan berguna untuk menentukan karakteristik para tokoh di dalam film dan terakhir adalah moodboard environment yang akan menentukan latar dan tempat di dalam film animasi ini. Berikut ini adalah moodboard fashion, karakter, dan environment dari film animasi Kapten Samadikun.

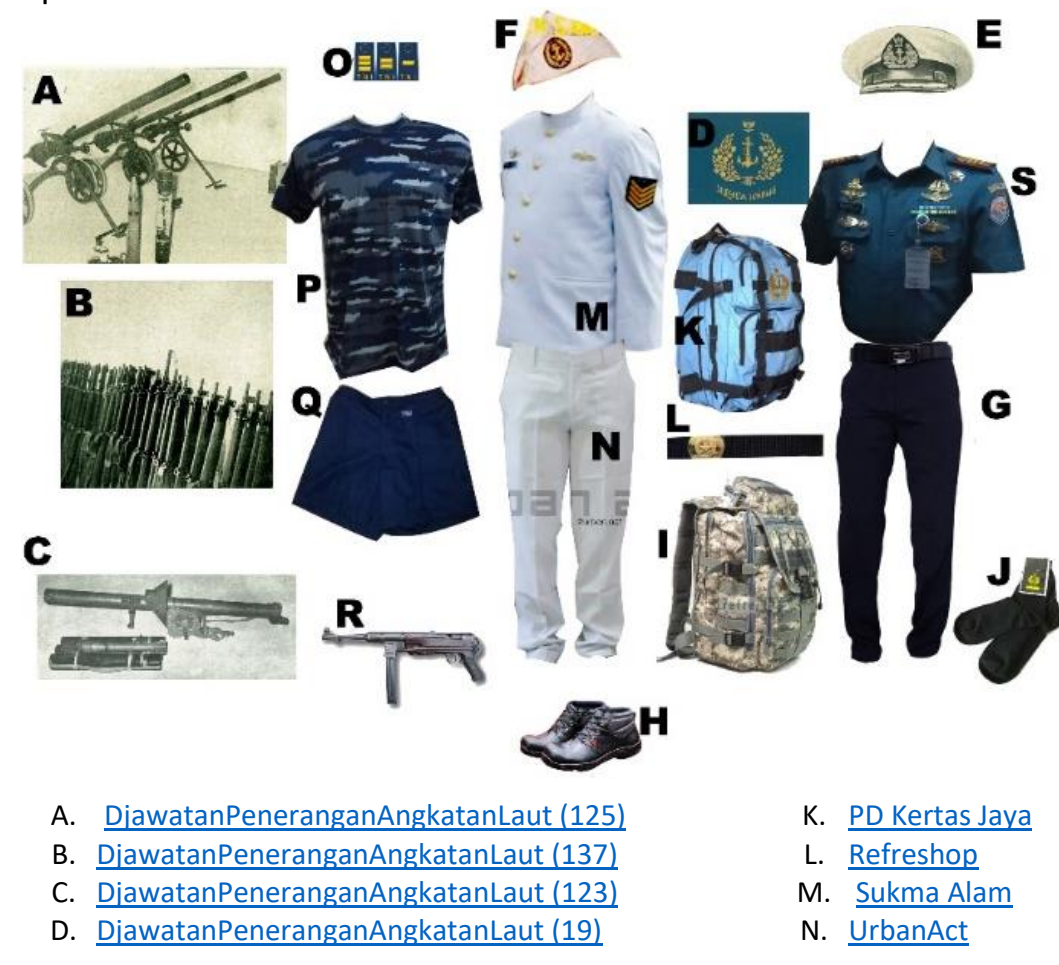



E. DjawatanPeneranganAngkatanLaut (109)
O. Zakky
F. Sanna (i)
P. Tokokitajaya
G. Dokumen pribadi
Q. Kasta Praja
H. Syafasepatu.com
R. Sinaga
I. Privosang
S. Dokumen pribadi, 2018

J. Toko Armed

\section{Gambar 5 Moodboard fashion}

Sumber: Dokumen pribadi, 2019

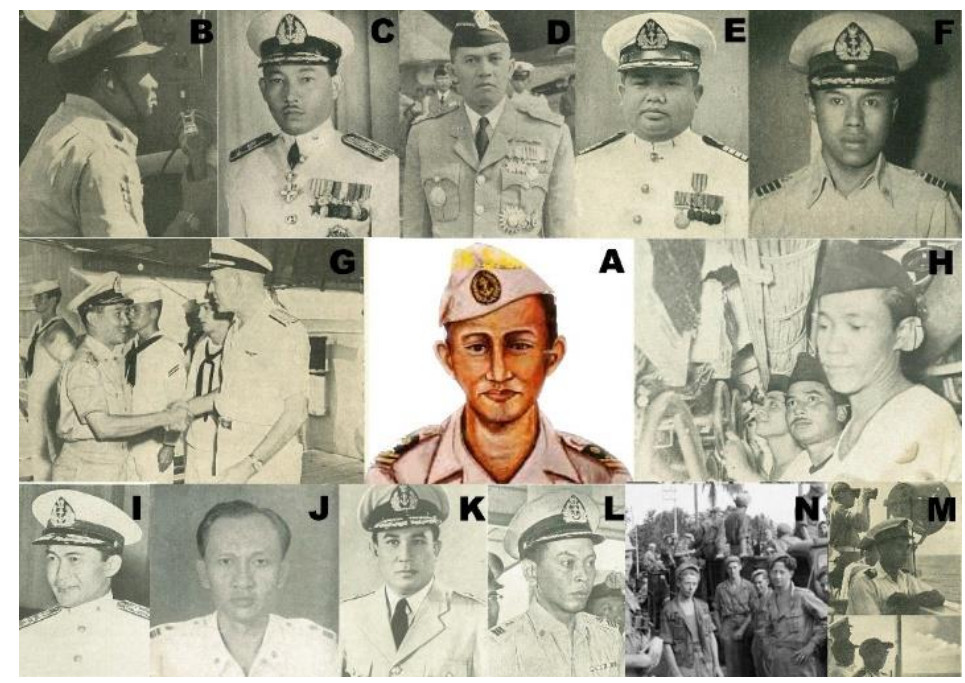
A. Sanna (i)
B. DjawatanPeneranganAngkatanLaut (40)
C. DjawatanPeneranganAngkatanLaut (13)
D. DjawatanPeneranganAngkatanLaut (11)
E. DjawatanPeneranganAngkatanLaut (109)
F. DjawatanPeneranganAngkatanLaut (28)
G. DjawatanPeneranganAngkatanLaut (48)

H. DjawatanPeneranganAngkatanLaut (190)

I. DjawatanPeneranganAngkatanLaut (212)

J. DjawatanPeneranganAngkatanLaut (213)

K. DjawatanPeneranganAngkatanLaut (215)

L. DjawatanPeneranganAngkatanLaut (212)

M. DjawatanPeneranganAngkatanLaut (58)

N. prasetya

\section{Gambar 6 Moodboard karakter}

Sumber: Dokumen pribadi, 2019

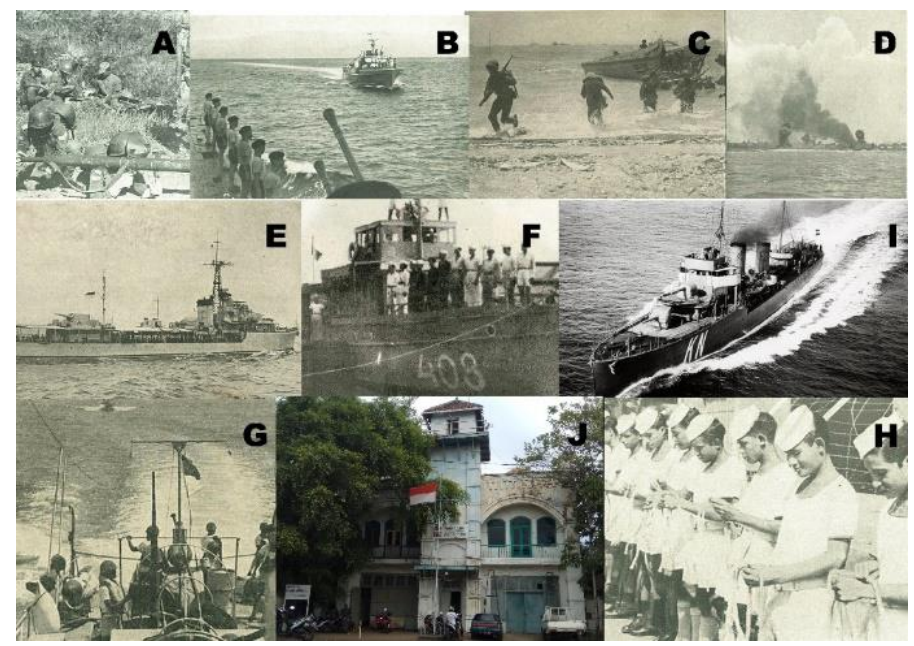
A. DjawatanPeneranganAngkatanLaut (123)
F. Dinas Sejarah TNI-AL (453)
B. DjawatanPeneranganAngkatanLaut (96)
G. DjawatanPeneranganAngkatanLaut (5) 
C. DjawatanPeneranganAngkatanLaut (34)

H. DjawatanPeneranganAngkatanLaut (223)

D. DjawatanPeneranganAngkatanLaut (208)

I. Taufiqqurahman

E. DjawatanPeneranganAngkatanLaut (32)

J. Dokumen pribadi, 2018

Gambar 7 Moodboard environment

Sumber: Dokumen pribadi, 2019

\section{Proses Perancangan}

Berdasarkan penelusuran yang dilakukan oleh peneliti, peneliti mendapatkan ilustrasi dari sosok Kapten Samadikun yang ada pada cover buku "Pahlawan Samudera Kapten Samadikun". Berdasarkan deskripsi dari buku tersebut Letnan I Samadikun atau sekarang Kapten (Anumerta) Samadikun berkulit putih dan wajahnya kemerah merahan jika kepanasan, kemudian perawakannya tidak terlalu besar. Dari segi fashion Letnan I Samadikun memakai seragam ALRI berwarna putih dan berpangkat Letnan I. Berikut ini adalah ilustrasinya.

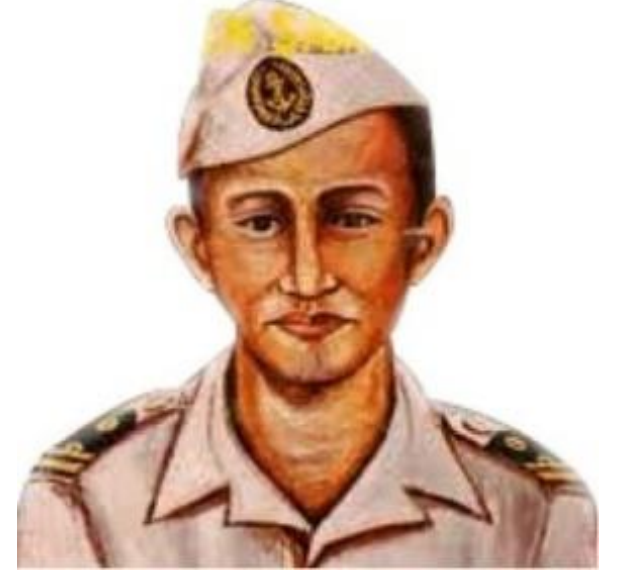

Gambar 8 Referensi Karakter Letnan I Samadikun Sumber: Sanna (i)
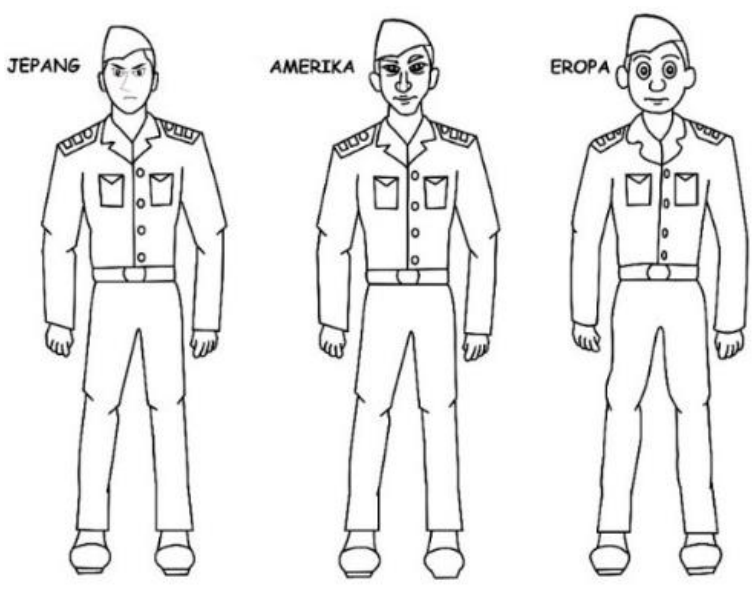

Gambar 9 Karakter dari berbagai gaya visual Sumber: Dokumen pribadi, 2018

Gambar di atas adalah beberapa gaya visual dari sosok Letnan I Samadikun. Dari gaya visual Jepang, Amerika dan Eropa peneliti memilih gaya visual Jepang atau lebih dikenal dengan gaya anime karena gaya ilustrasi tersebut merupakan gaya visual yang sederhana dan dapat mudah dicerna oleh khalayak remaja.
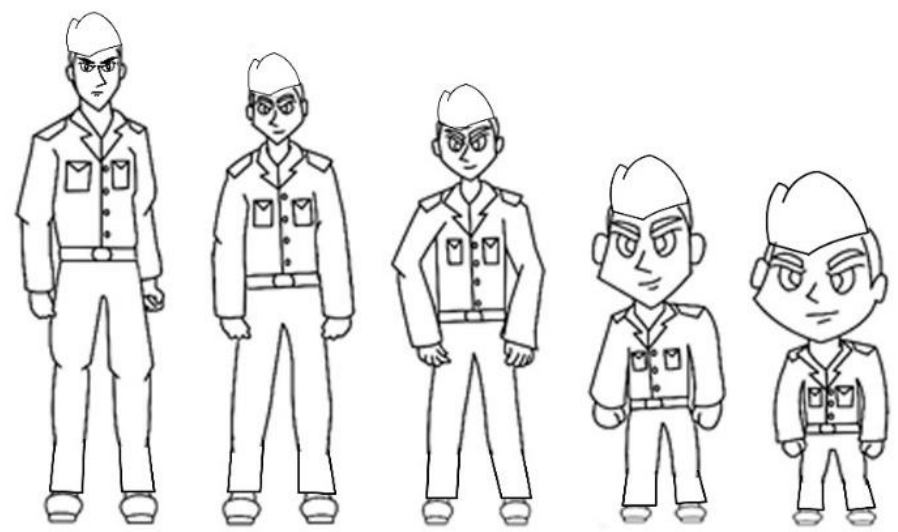

Alternatif 1 Alternatif 2 Alternatif 3 Alternatif 4 Alternatif 5

Gambar 10 Alternatif karakter Letnan I Samadikun

Sumber: Dokumen pribadi, 2018 
Gambar di atas merupakan beberapa alternatif karakter yang akan diterapkan dalam film animasi Pahlawan Samudra Kapten Samadikun. Peneliti memilih alternatif karakter nomor satu karena memiliki visual yang mendekati proporsi tubuh manusia yang sebenarnya sesuai dengan target khalayak yaitu para remaja. Karena alternatif nomor dua sampai lima lebih cocok ditujukan untuk golongan umur dibawah remaja.

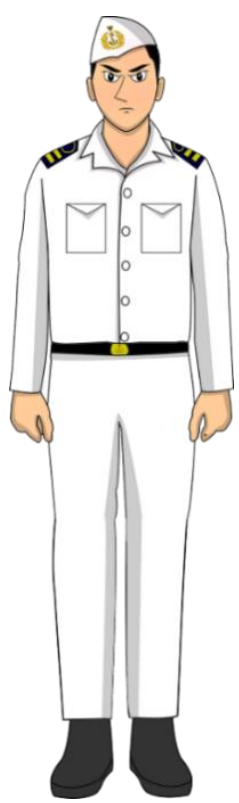

Gambar 11 Karakter pilihan Letnan I Samadikun Sumber: Dokumen pribadi, 2018

Gambar di atas adalah ilustrasi karakter terpilih yang sudah melalui proses digitalisasi dan akan diterapkan pada seluruh isi film animasi yang akan peneliti rancang sebagai pemeran utama Letnan I Samadikun sebagai komandan kapal Gajah Mada.
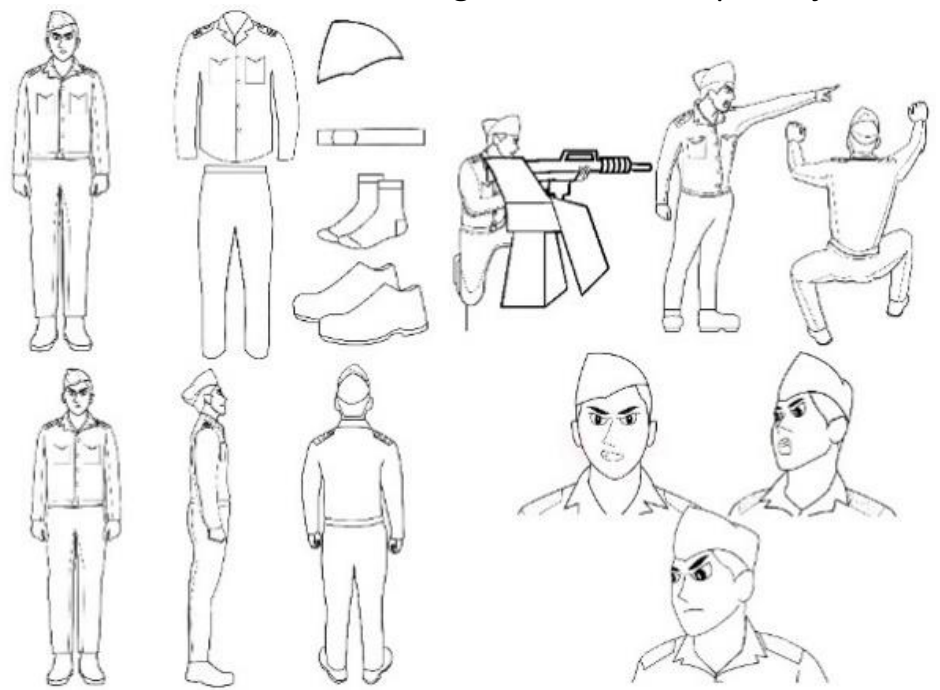

Gambar 12 Sketsa karakter Letnan I Samadikun Sumber: Dokumen pribadi, 2019 


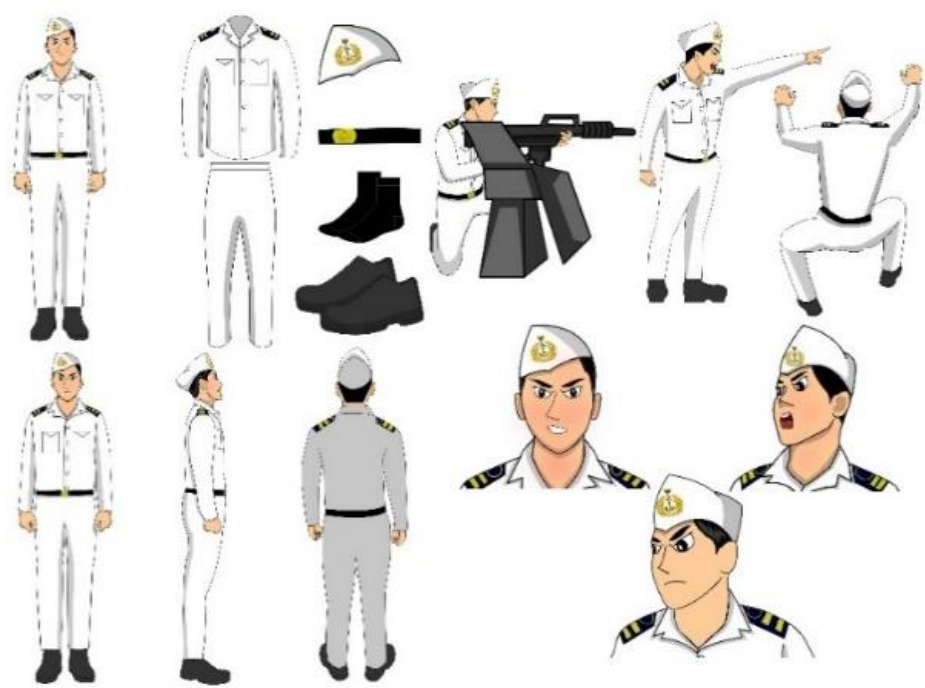

Gambar 13 Final artworks karakter Letnan I Samadikun Sumber: Dokumen pribadi, 2019

Gambar di atas merupakan sketsa manual dan digital dari berbagai tampak, gesture atau gerakan, fashion, dan ekspresi dari karakter utama Letnan I Samadikun yang disesuaikan dengan karakter aslinya dengan teknik deformasi atau penyederhanaan desain dengan tetap menonjolkan ciri khas utamanya yaitu peneliti tetap menonjolkan fashion Letnan I Samadikun meliputi pangkat, seragam dan atribut lainnya.

Peneliti berhasil mendapatkan referensi karakter dari sosok G.B. Fortuyn melalui media daring. Ilustrasi dari sosok G.B Fortuyn adalah berkulit putih, berambut pirang, memiliki postur tubuh yang tinggi, memakai topi dan memakai seragam jas berwarna hitam. Berikut adalah beberapa referensi foto dari G.B Fortuyn.
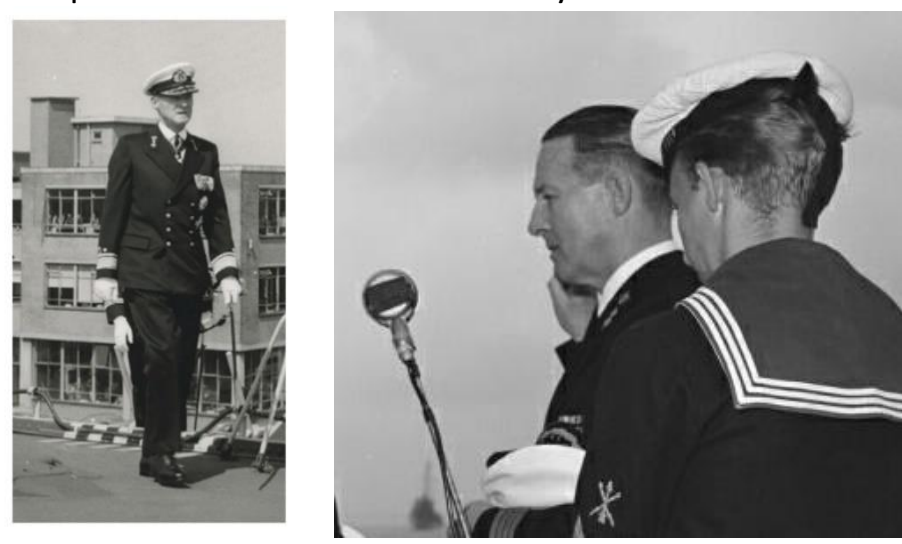

Gambar 14 Referensi Karakter G. B. Fortuyn 1

Sumber: Audiovisuele dienst koninklijkemarine 


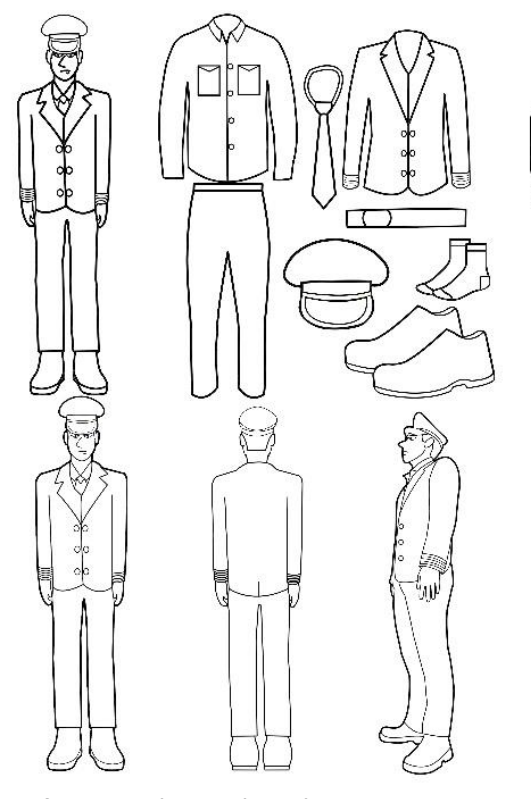

Gambar 15 Sketsa karakter G. B. Fortuyn Sumber: Dokumen pribadi, 2019

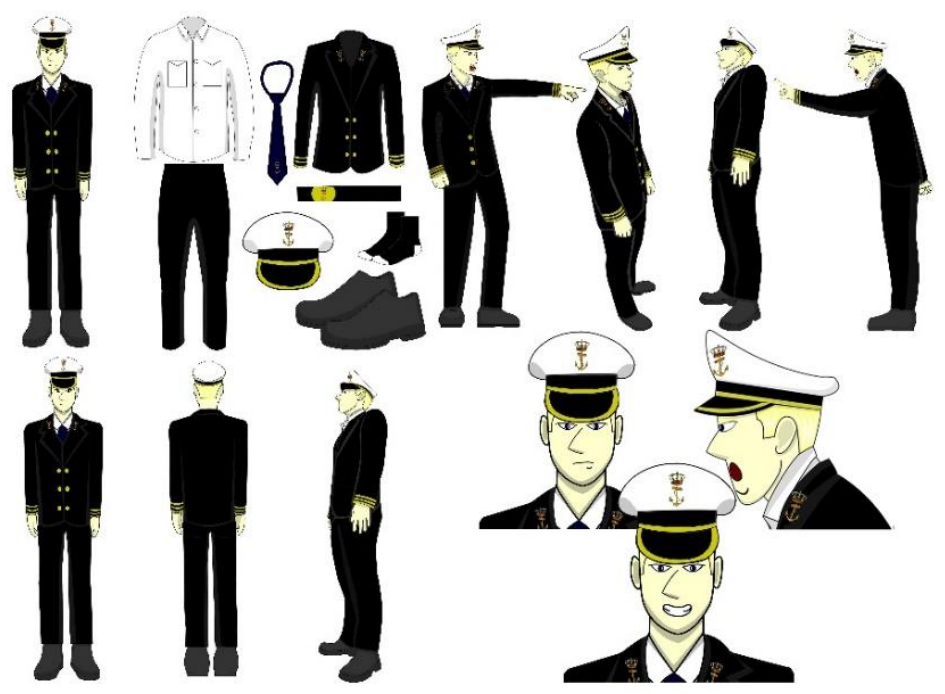

Gambar 16 Final artworks G. B. Fortuyn Sumber: Dokumen pribadi, 2019

Gambar di atas merupakan sketsa manual dan digital dari berbagai tampak, gesture atau gerakan, fashion, dan ekspresi dari karakter pendukung G.B. Fortuyn yang merupakan lawan dari Letnan I Samadikun. Dengan teknik deformasi peneliti juga tetap menonjolkan sisi fashion dari G.B. Fortuyn yang memakai jas hitam, celana hitam dan mengenakan topi.

Berikut ini adalah referensi dari karakter Sukartin yang merupakan peran pendukung sebagai ayah Kapten Samadikun. Peneliti mendapatkan referensi tersebut dari sebuah buku berjudul "Pahlawan Samudra Kapten Samadikun". Penggambarannya adalah memakai kacamata, memakai peci hitam dan berkemaja berwarna putih. Berikut ini adalah gambarnya. 


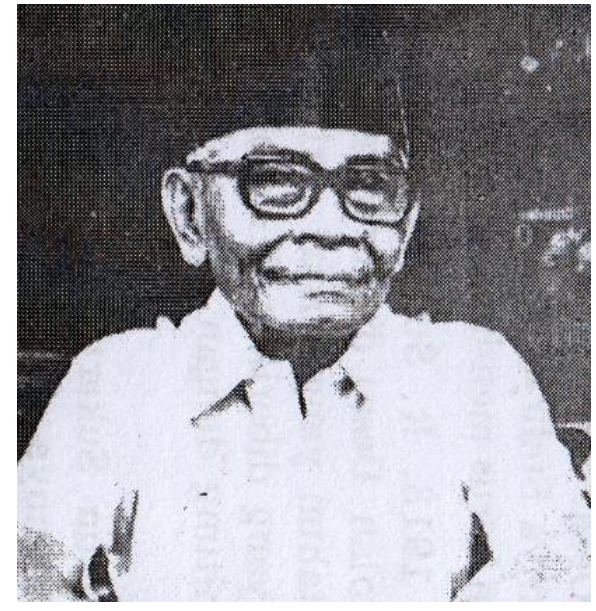

Gambar 17 Referensi karakter Sukartin Sumber: Sanna (4)

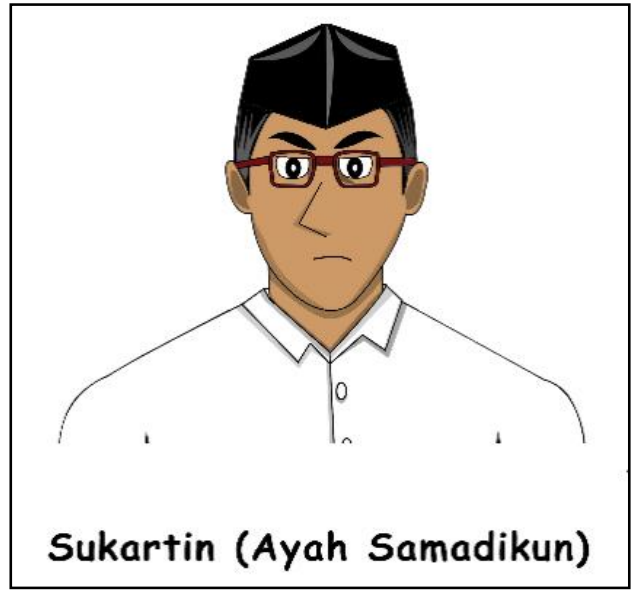

Gambar 18 Final artwork Sukartin Sumber: Dokumen pribadi, 2019

Gambar di atas merupakan sketsa manual dan digital dari karakter ayah Kapten Samadikun yaitu Sukartin dengan gaya anime dan teknik yang sama yaitu deformasi dengan tetap menonjolkan ciri khas utamanya yaitu peneliti tidak menghilangkan segi fashion yaitu memakai peci berwarna hitam, memakai kacamata dan berbaju putih.

Berikut ini adalah referensi dari karakter Kasinah yang merupakan peran pendukung sebagai ibu dari Kapten Samadikun. Peneliti mendapatkan referensi gambar tersebut dari sebuah buku berjudul "Pahlawan Samudra Kapten Samadikun". Penggambarannya adalah berkulit putih dengan rambut terikat kebelakang dan memakai kain batik.
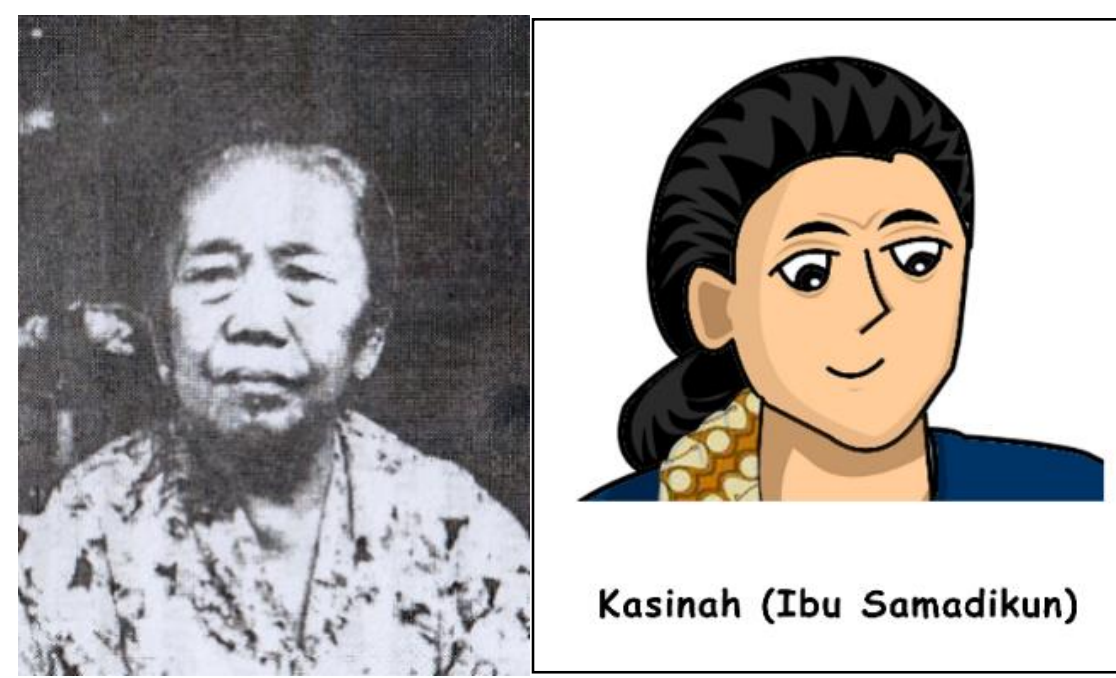

\section{Kasinah (Ibu Samadikun)}

Gambar 19 Referensi karakter dan sketsa karakter Kasinah

Sumber: Sanna (4) 


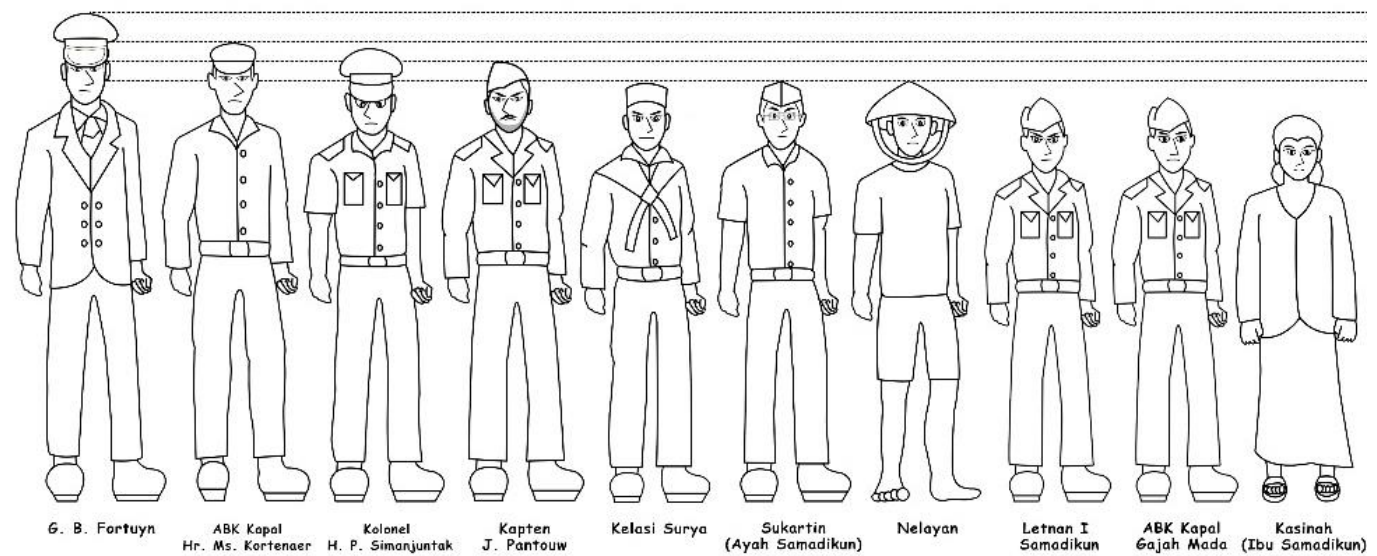

Gambar 20 Perbandingan skalatis karakter Sumber: Dokumen pribadi, 2019

Gambar di atas merupakan perbandingan skalatis karakter bahwa digambarkan karakter G. B. Fortuyn adalah karakter paling tinggi dan Kasinah menjadi karakter paling pendek, sementara itu karakter utama Letnan I Samadikun sama tingginya dengan anak buah kapal Gajah Mada dan lebih tinggi beberapa sentimeter dengan ibunya yaitu Kasinah. Penggambaran skalatis ini berdasarkan sumber literatur pahlwan samudra Kapten Samadikun yang mengatakan bahwa Kapten Samadikun tidak memiliki postur yang tinggi dan besar.

Sedangkan untuk proses latar suasana, penulis merancang beberapa kondisi suasana yang terjadi pada cerita animasi. Frobel Neutrale School merupakan sekolah setara dengan taman kanak-kanak, pada masa itu Kapten Samadikun sekolah di Frobel Neutrale School di Bandung. Referensi gambar tersebut merupakan referensi gambar yang sebenarnya yang didapatkan melalui media daring. Latar tersebut akan diterapkan pada segmen satu.

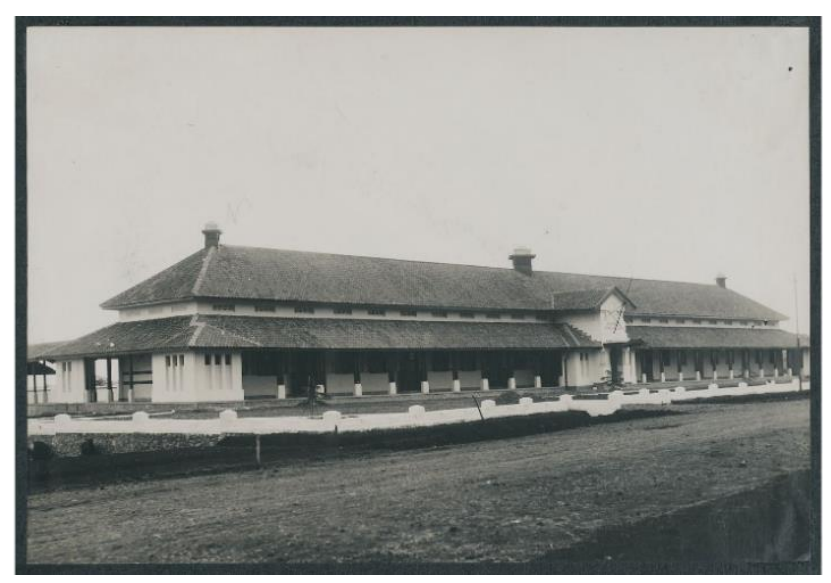

Gambar 21 Studi latar Frobel Neutrale School Sumber: KITLV "Het Gebouw Van De Neutrale School Van De Bandoengsche Schoolvereniging Te Bandoeng" 


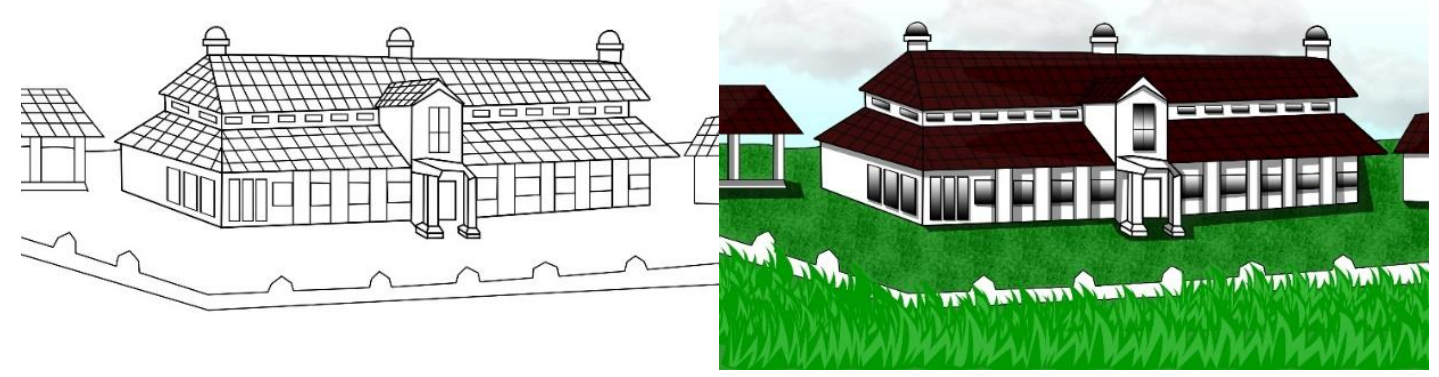

Gambar 22 Sketsa Frobel Neutrale School

Sumber: KITLV "Het Gebouw Van De Neutrale School Van De Bandoengsche Schoolvereniging Te Bandoeng"

MULO atau Meer Uitgebreid Lager Onderwijs merupakan sekolah setara dengan sekolah menengah pertama, pada masa itu Kapten Samadikun sekolah di MULO Jakarta. Referensi gambar ini juga merupakan gambar MULO yang sebenarnya yang peneliti dapatkan dari media daring.

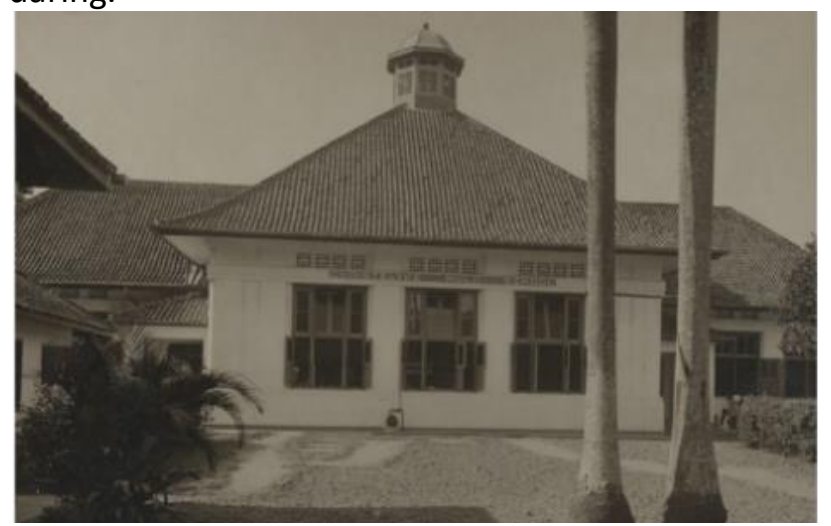

Gambar 23 Studi latar MULO school

Sumber: KITLV "Christelijke Mulo School Aan De Gang Mendjangan Te Batavia"

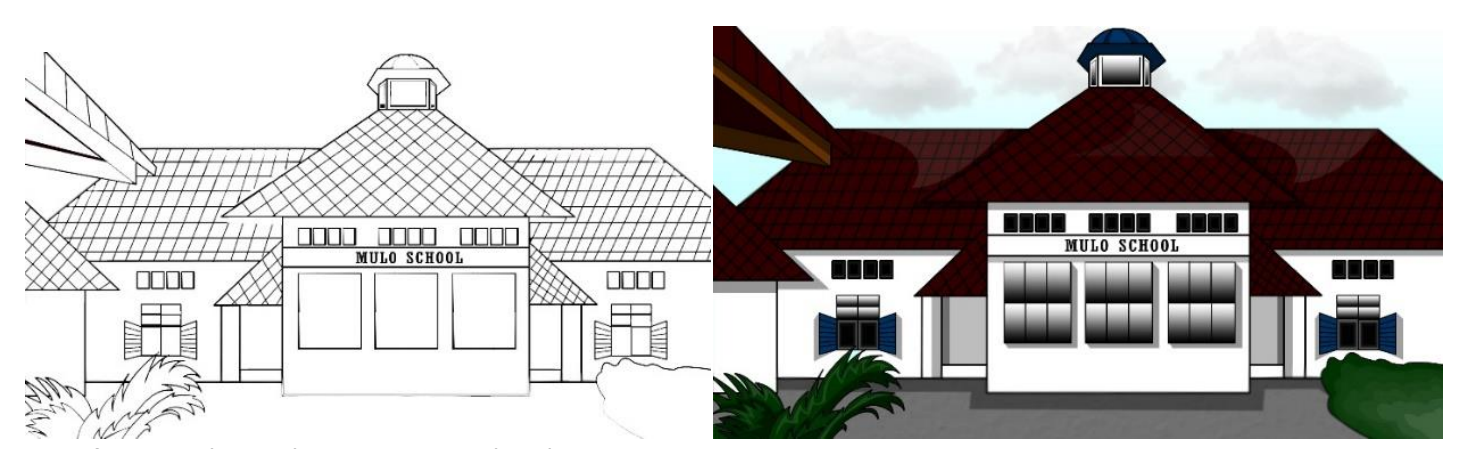

Gambar 24 Sketsa latar MULO school

Sumber: Dokumen pribadi, 2019

Pangkalan III Cirebon merupakan sebuah markas dari anggota ALRI Cirebon tahun 1946 letaknya di Pelabuhan Cirebon, hingga saat ini bangunan tersebut masih berdiri kokoh. Gambar tersebut merupakan gambar sebenarnya peneliti mendapatkannya melalui observasi secara langsung di Pelabuhan Cirebon dan bangunan ini masih utuh akan tetapi sudah beralih fungsi menjadi gudang bongkar muat barang. 


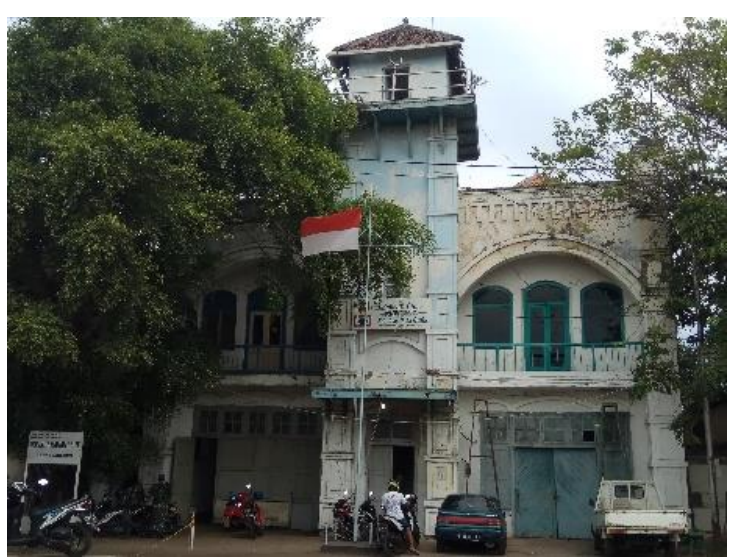

Gambar 25 Studi latar Pangkalan III Cirebon Sumber: Dokumen pribadi, 2019

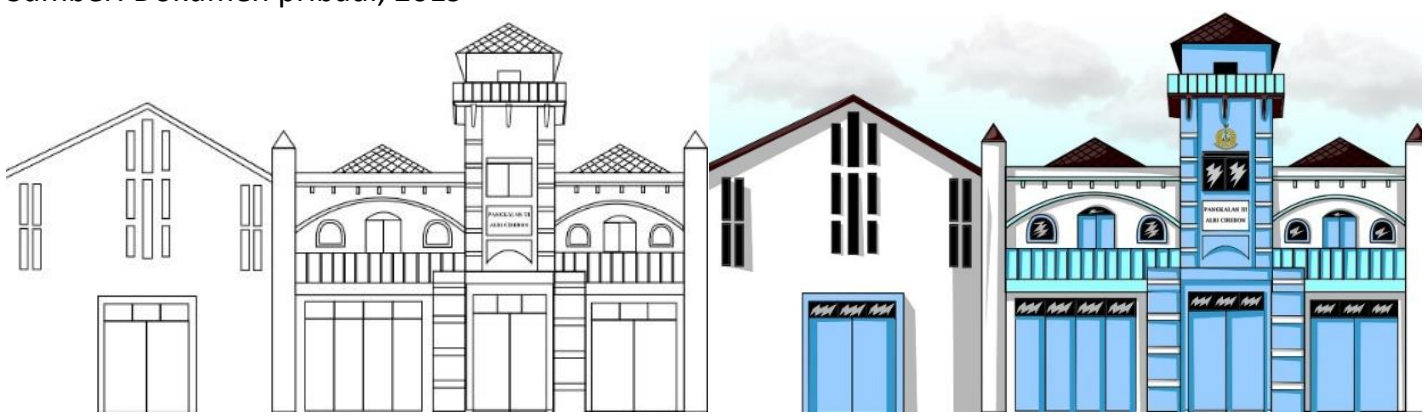

Gambar 26 Final artworks latar Pangkalan III Cirebon

Sumber: Dokumen pribadi, 2019

Hasil akhir dari perancangan film animasi "Pahlawan Samudra Kapten Samadikun" adalah berbentuk animasi dua dimensi (2D) berformat video $\mathrm{mp4}$, dengan konsep yang telah ditetapkan. Film ini akan didistribusikan pada sekolah-sekolah menengah pertama (SMP) di Kota Cirebon dan Perpustakaan 400 Cirebon, bekerja sama dengan Dinas Pendidikan Kota Cirebon dan Pemerintah Daerah Kota Cirebon tujuannya adalah agar mempermudah dalam proses pendistribusian film tersebut kepada target khalayak.

Pada bagian awal film animasi ditampilkan sebuah cover yang mewakili isi dari film animasi tersebut yaitu sebuah gambar Letnan I Samadikun sedang berperang di atas anjungan kapal Gajah Mada yang terbakar. Kemudian dilanjutkan dengan tampilan judul film "Pahlawan Samudra Kapten Samadikun" yang menggunakan efek-efek api untuk menghadirkan kesan membara dan dramatis. Berikut ini adalah tampilannya.

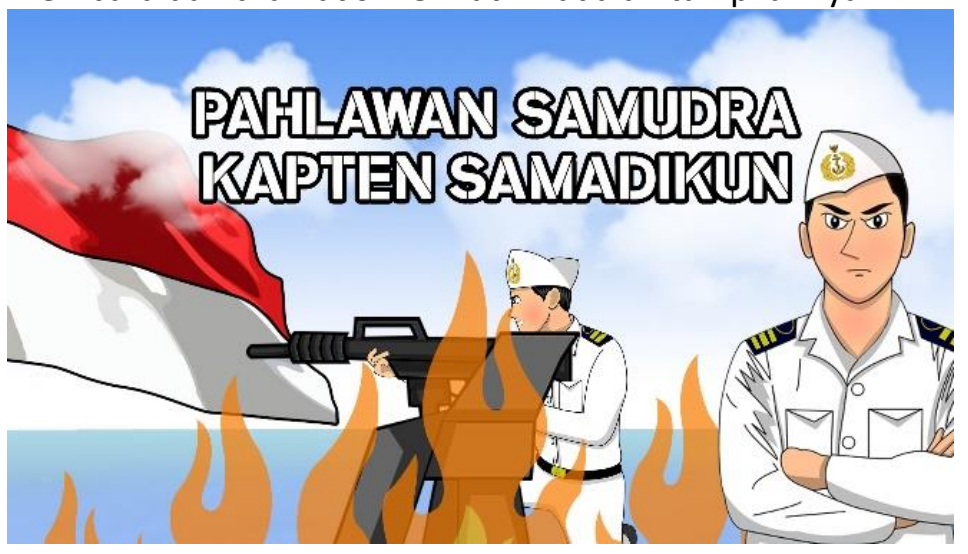




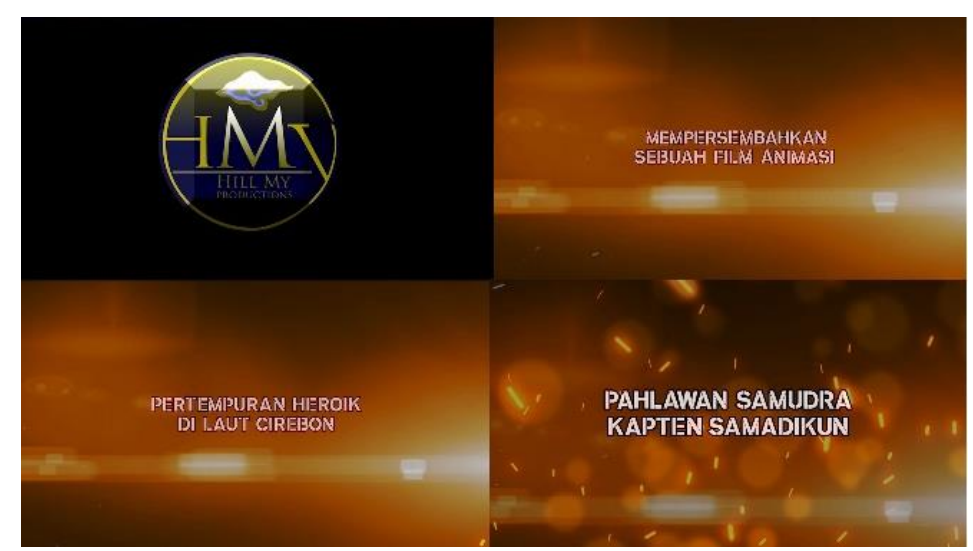

Gambar 27 Printscreen pembuka film animasi Sumber: Dokumen pribadi, 2019

Berikut ini adalah scene-secene yang menampilkan beberapa adegan dalam film animasi Pahlawan Samudra Kapten Samadikun. Film ini terbagi menjadi empat segmen. Berikut ini adalah pembagian dalam setiap segmennya. Pada segmen pertama film animasi akan menampilkan adegan yang mengulas mengenai asal-usul dari Kapten Samadikun dengan ditampilkan secara naratif.

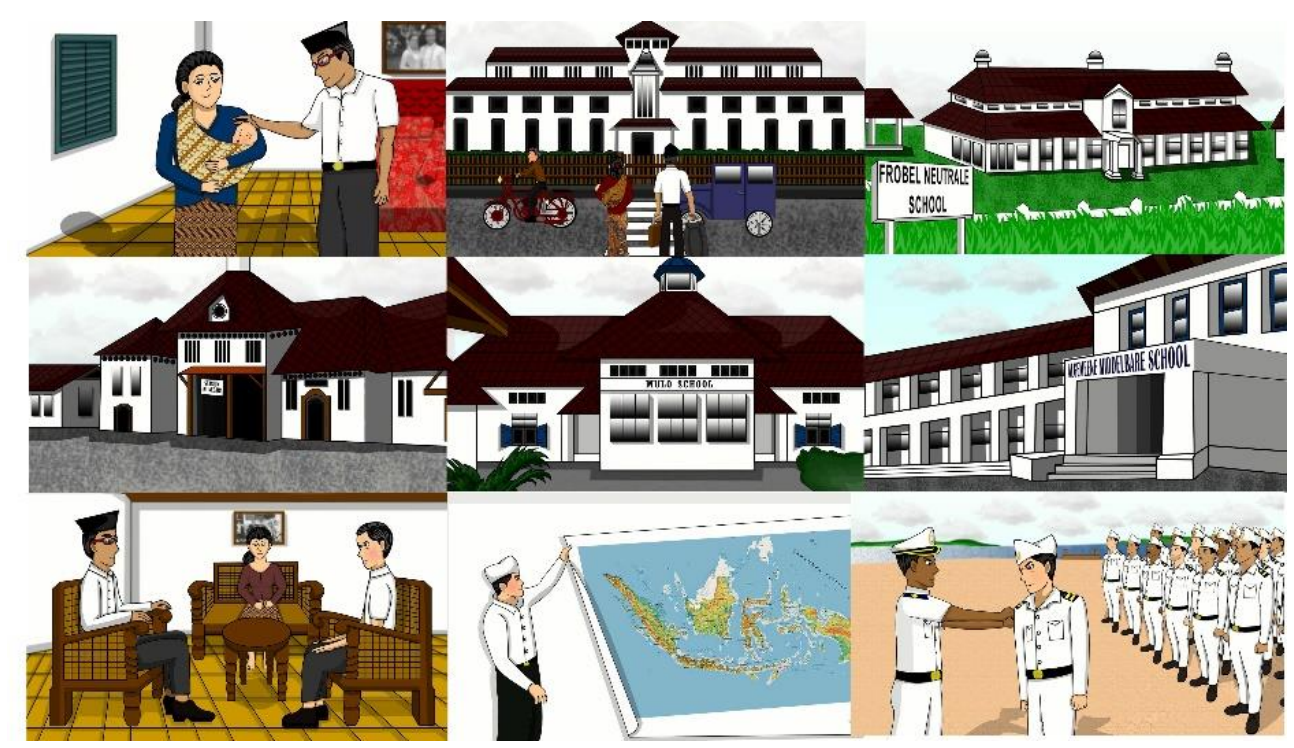

Gambar 28 Printscreen Segmen 1

Sumber: Dokumen pribadi, 2019

Pada segmen selanjutnya merupakan sebuah adegan-adegan dimulainya latihan berperang ALRI (Angkatan Laut Republik Indonesia) yang dipimpin langsung oleh komandan Eskader Letnan I Samadikun. 


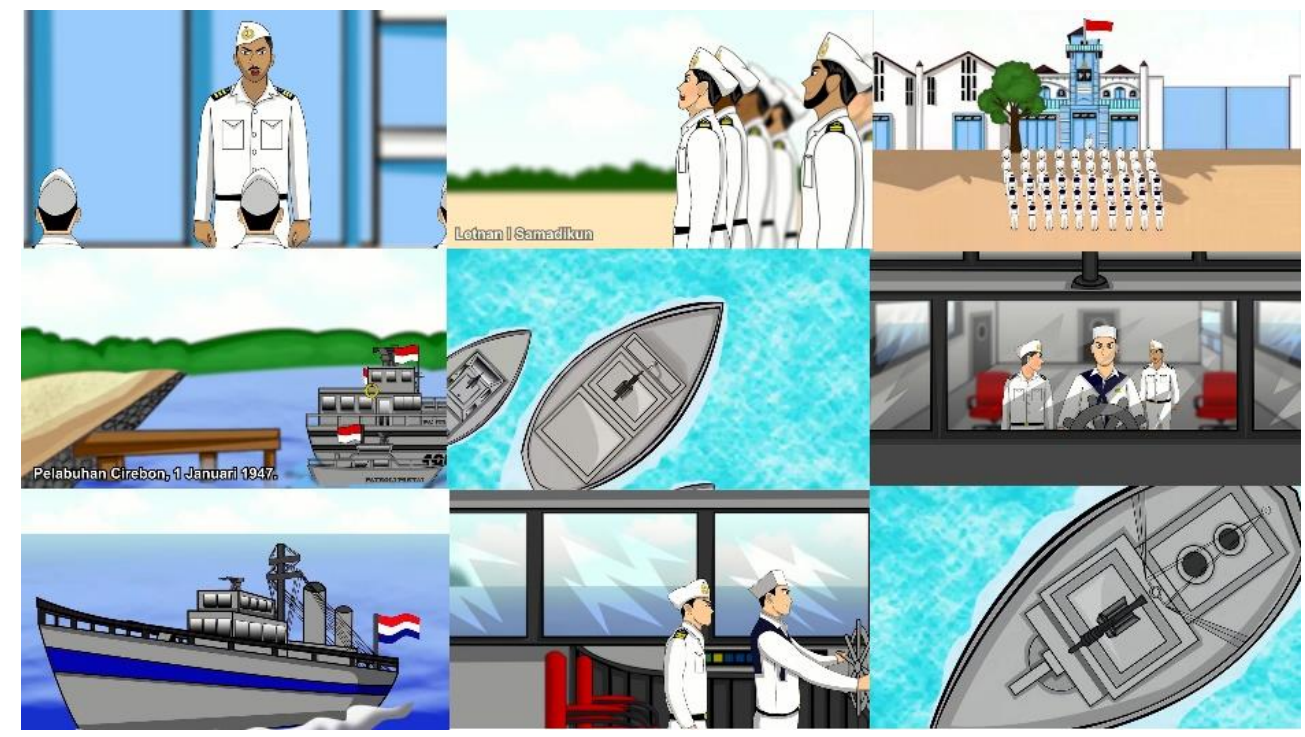

Gambar 29 Printscreen Segmen 2

Sumber: Dokumen pribadi, 2019

Pada segmen ini merupakan awal mula terjadinya pertempuran laut di Cirebon yaitu karena Letnan I Samadikun gagal menghindari kapal Belanda dan berpapasan secara tidak sengaja.

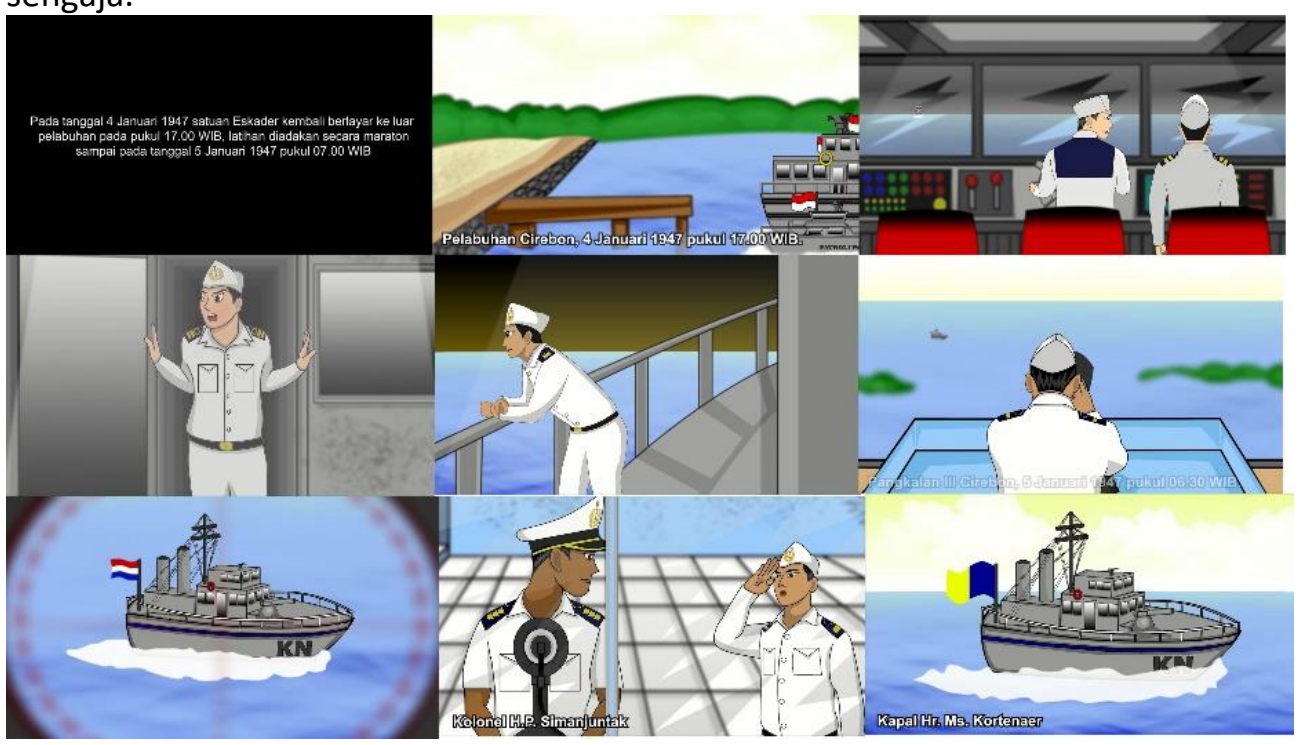

Gambar 30 Printscreen Segmen 3

Sumber: Dokumen pribadi, 2019

Pada segmen keempat merupakan babak terakhir yang menceritakan gugurnya Letnan I Samadikun yang terkena tembakan terakhir dari kapal Belanda dan jasadnya ditemukan oleh nelayan yang sedang mencari ikan. 


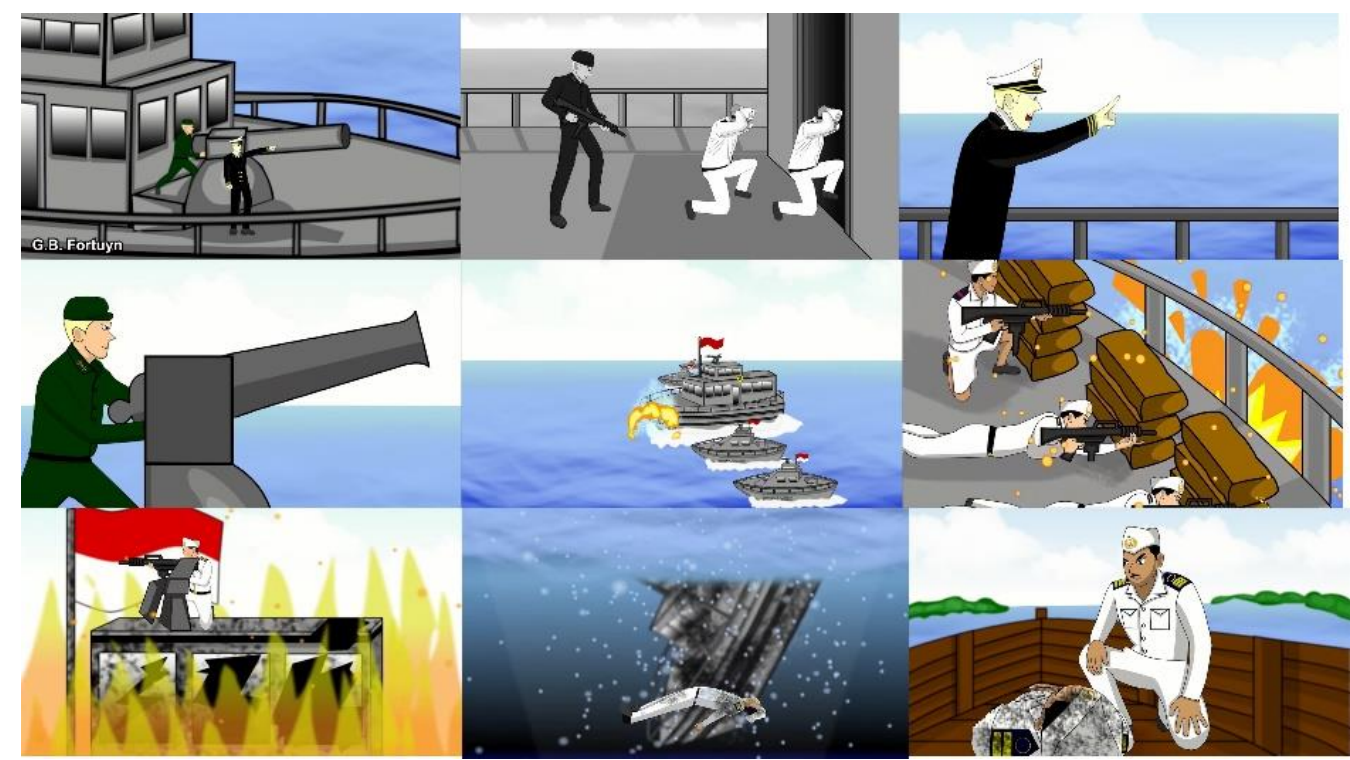

Gambar 31 Printscreen Segmen 4

Sumber: Dokumen pribadi, 2019

Berikut ini adalah bagian penutup dengan konsep yang sama dengan bagian pembuka dan dilengkapi dengan end tittle dan credit tittle.

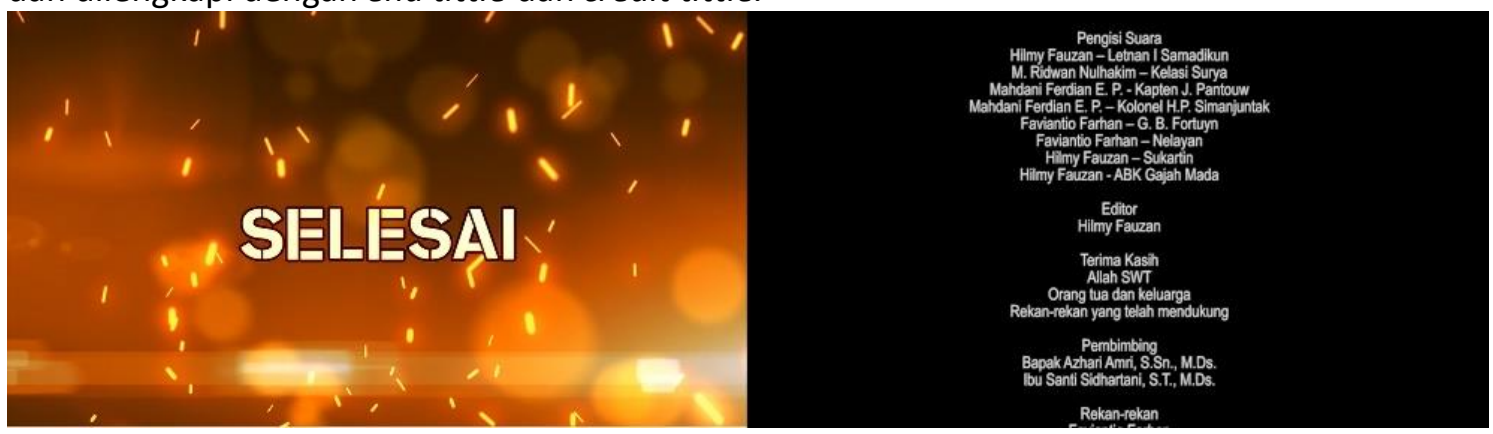

Gambar 32 Printscreen penutup film animasi

Sumber: Dokumen pribadi, 2019

Demikian hasil penelitian berbasis perancangan film animasi, diharapkan para remaja mengenal sosok Kapten Samadikun dan dapat meneladani sifat-sifat nasionalisme dan patriotisme dari Kapten Samadikun.

\section{Simpulan}

Setelah melakukan proses penelitian, observasi, wawancara, serta serangkaian proses perancangan media utama hingga media pendukung. Peneliti dapat menarik beberapa simpulan, diantaranya adalah:

1. Kapten Samadikun merupakan sosok yang sangat penting bagi remaja untuk dijadikan sosok identifikasi atau panutan karena telah memperjuangkan harga diri bangsa Indonesia serta dengan sadar telah rela mengorbankan jiwa raganya demi bangsa Indonesia pada pertempuran laut di Cirebon 5 Januari 1947. Kapten Samadikun adalah sosok yang pantang menyerah selain itu beliau juga sangat bertanggung jawab atas keselamatan anggotanya, 
oleh karena itu Kapten Samadikun dianugerahi penghargaan sebagai Pahlawan Samudra dan pangkatnya dinaikkan secara Anumerta dari Letnan I menjadi Kapten Samadikun.

2. Kisah pertempuran heroik Kapten Samadikun merupakan contoh yang baik bagi remaja untuk bisa menumbuhkan rasa nasionalisme dan patriotisme pada diri mereka masingmasing, oleh karena itu target utama dari peneliti adalah para remaja. Karena masalah pada remaja pada saat ini adalah kurang mencintai budaya dan sejarah bangsanya sendiri dan remaja juga merupakan pondasi bangsa yang harus dibentuk sejak dini dengan baik.

3. Peneliti memilih film animasi untuk mengenalkan kisah heroik Kapten Samadikun kepada khalayak karena media film animasi adalah media yang dinamis dan digemari oleh sebagian besar khalayak remaja. Selain itu media animasi juga merupakan media yang kompleks, karena mencakup audio dan visual sehingga dapat menarik minat para remaja untuk mempelajari ilmu sejarah melalui film animasi.

4. Perancangan media film animasi yang berjudul "Pahlawan Samudra Kapten Samadikun" menggunakan konsep visual bergaya anime. Kemudian jenis transisi yang digunakan pada film adalah dissolve, yaitu teknik untuk menghaluskan proses pemindahan gambar. Skema warna yang digunakan adalah hitam, putih, abu-abu dan biru. Warna-warna tersebut digunakan sebagai warna fashion karakter, latar kapal dan warna samudra atau laut. Jenis gaya warna yang digunakan dalam film ini yaitu bergaya pop art, gaya ini dipilih berdasarkan kepada segmentasi target khalayak yaitu remaja. Audio yang digunakan adalah stereo dengan teknik recording menggunakan gawai dan peneliti menggunakan backsound yang disesuaikan dengan adegan yang ada di dalam film. Typeface yang ada di dalam film ini mengutamakan ketegasan, kejelasan dan tingkat keterbacaan yang tinggi agar target khalayak dapat benar-benar memahami pesan dan informasi yang terdapat dalam film animasi "Pahlawan Samudra Kapten Samadikun".

\section{Daftar Pustaka}

Arifin, Yulyani et al. Digital Multimedia. PT. Widia Inovasi Nusantara, 2015.

Audiovisuele dienst koninklijke Marine. "G.B. Fortuyn." edited by Beëdiging a/b van de bij Oran voor anker liggende kruiser Hr.Ms. De Zeven Provinciën (C 802) door de commandant van 'De Zeven' kapitein-ter-zee G.B. Fortuyn (1907-1972, tweede van rechts), januari 1956., 1956. https://nimh-beeldbank.defensie.nl/memorix/2c36845a-2430-0459-7bea780b38fa7799https://nimh-beeldbank.defensie.nl/memorix/2c36845a-2430-04597bea-780b38fa7799, 15 April 2019.

Dahuri, Rokhmin et al. Budaya Bahari: Sebuah Apresiasi Di Cirebon. Perum Percetakan Negara RI, 2004.

Dinas Sejarah TNI-AL. Sejarah Tentara Nasional Indonesia Angkatan Laut (Periode Perang Kemerdekaan 1945-1950). Dinas Sejarah TNI-AL, 1973.

DjawatanPeneranganAngkatanLaut. Jalesveva Jayamahe. Djawatan Penerangan Angkatan Laut, 1960.

Kasta Praja. "Celana Pendek Olahraga Tni." 2018. https://www.tokopedia.com/kastapraja/celana-pendek-olah-ragatni?trkid=f=Ca0000LO0OPOWOSOSh,CoOPoOFrOCb0 src=search page=1 ob=23 $\mathrm{q}=$ celan a+pendek+tni po=8 catid=1516https://www.tokopedia.com/kasta-praja/celana- 
pendek-olah-raga-

tni?trkid=f=Ca0000L000POWOSOSh, CoOPoOFrOCbO src=search page=1 ob=23 $\mathrm{q}=$ celan a+pendek+tni po=8 catid=1516, 14 Juli 2019.

KITLV. "Christelijke Mulo School Aan De Gang Mendjangan Te Batavia." edited by KITLV 154654, Leiden University Libraries,

1925. https://digitalcollections.universiteitleiden.nl/view/item/890003?solr nav\%5Bid\%5D=f 380bf34a6b5338108ec\&solr nav\%5Bpage\%5D=0\&solr nav\%5Boffset\%5D=0https://di gitalcollections.universiteitleiden.nl/view/item/890003?solr nav\%5Bid\%5D=f380bf34a 6b5338108ec\&solr nav\%5Bpage\%5D=0\&solr nav\%5Boffset\%5D=0, 15 April 2019.

KITLV. "Het Gebouw Van De Neutrale School Van De Bandoengsche Schoolvereniging Te Bandoeng." edited by KITLV 11874, Leiden University Libraries, 1920. https://digitalcollections.universiteitleiden.nl/view/item/910604?solr nav\%5Bid\%5D= 5da54b424b808f2408d7\&solr nav\%5Bpage\%5D=0\&solr nav\%5Boffset\%5D=0https:// digitalcollections.universiteitleiden.nl/view/item/910604?solr nav\%5Bid\%5D=5da54b 424b808f2408d7\&solr nav\%5Bpage\%5D=0\&solr nav\%5Boffset\%5D=0, 15 April 2019.

Munir. Multimedia Konsep Dan Aplikasi Dalam Pendidikan. CV Alfabeta, 2012.

PD Kertas Jaya. "Tas Tni Al - Tas Al Biru." 2014. http://kertajayaindonesia.strikingly.com/http://kertajayaindonesia.strikingly.com/, 10 Desember 2018.

Prasetya, Roy. "Belanda Kucurkan Dana 60 M Untuk Teliti Perang Kemerdekaan Indonesia." 2017. https://www.militer.or.id/6006/belanda-kucurkan-dana-60-m-untuk-telitiperang-kemerdekaan-indonesia/https://www.militer.or.id/6006/belanda-kucurkandana-60-m-untuk-teliti-perang-kemerdekaan-indonesia/, 14 Juli 2019.

Priyosang. "Tentang Tas Ransel Militer Tentara Tni Polisi Dan Kedinasan." 2013. https://id.pinterest.com/pin/857865428989762315/https://id.pinterest.com/pin/8578 65428989762315/, 14 Juli 2019.

Purnomo, Wahyu and Wahyu Andreas. Teknik Animasi 2d. Kementerian Pendidikan \& Kebudayaan Republik Indonesia, 2013.

Rahman, Agus Abdul. Psikologi Perkembangan Anak \& Remaja. CV Pustaka Setia, 2016.

Refreshop. "Ikat Pinggang Tni Al." 2013. https://refreshop.net/ikat-pinggang/ikat-pinggang-tniad-al-au-ipkt1-kokoh-awet-mewah-elegan/https://refreshop.net/ikat-pinggang/ikatpinggang-tni-ad-al-au-ipkt1-kokoh-awet-mewah-elegan/, 14 Juli 2019.

Rochman, Faizal et al. Rencana Pengembangan Animasi Nasional 2015-2019. PT. Republik Solusi, 2015.

Sanna, Burhannudin. Pahlawan Samudera Kapten Samadikun. Dinas Sejarah TNI-AL, 1976.

Saryono and Mekar Dwi Anggraeni. Metodologi Penelitian Kualitatif Dalam Bidang Kesehatan. Nuha Medika, 2010.

Sinaga, Erik. "Pistol Mitraliur Yang Ditanam Di Depok: Digunakan Sejak Pd I Saat Perang Parit, Invasi Jerman." 2018. https://iakarta.tribunnews.com/2018/04/06/pistol-mitraliur- 
yang-ditanam-di-depok-digunakan-sejak-pdi-i-saat-perang-parit-invasijerman?page=allhttps://jakarta.tribunnews.com/2018/04/06/pistol-mitraliur-yangditanam-di-depok-digunakan-sejak-pdi-i-saat-perang-parit-invasi-jerman?page=all, 14 Juli 2019.

Subaryana. "Building the Positive Self-Concept through Patriotism." Dinamika Jurnal Ilmiah Pendidikan Dasar, vol. 8, no. 1, 2016, pp. 26-33, http://www.jurnalnasional.ump.ac.id/index.php/Dinamika/article/view/939.

Sudharmono. 30 Tahun Indonesia Merdeka 1945-1949. PT. Citra Lamtoro Gung Persada, 1986.

Sukiyasa, Kadek and Sukoco. "Pengaruh Media Animasi Terhadap Hasil Belajar Dan Motivasi Belajar Siswa Materi Sistem Kelistrikan Otomotif." Jurnal Pendidikan Vokasi, vol. 3, no. 1, 2013, pp. 126-137, doi:https://doi.org/10.21831/jpv.v3i1.1588.

Sukma Alam. "Intip Yuk Perbedaan Seragam Tni Ad, Al Dan Au." 2018. http://rilis.id/intip-yukperbedaan-seragam-tni-ad-al-dan-auhttp://rilis.id/intip-yuk-perbedaan-seragam-tniad-al-dan-au, 14 Juli 2019.

Syafasepatu.com. "Sepatu Pria Kickers Safety Boots Ky Black." 2019. http://syafasepatu.com/sepatu-pria-kickers-safety-boots-ujung-besi.html/sepatu-priakickers-safety-boots-ky-blackhttp://syafasepatu.com/sepatu-pria-kickers-safety-bootsujung-besi.html/sepatu-pria-kickers-safety-boots-ky-black, 14 Juli 2019.

Syahfitri, Yunita. "Teknik Film Animasi Dalam Dunia Komputer." Journal Saintikom, vol. 10, no. 3, 2011, pp. 213-217, https://prpm.trigunadharma.ac.id/public/fileJurnal/hpqo5Jurnal-YUN-animasi.pdf.

Taufiqqurahman, Muhammad. "Ini Foto 3 Kapal Perang Belanda Yang Bangkainya Hilang Di Indonesia. Royal Navy Official Photographer " 2016. https://news.detik.com/berita/d3348196/ini-foto-3-kapal-perang-belanda-yang-bangkainya-hilang-diindonesiahttps://news.detik.com/berita/d-3348196/ini-foto-3-kapal-perang-belandayang-bangkainya-hilang-di-indonesia, 5 Juni 2019.

Toko Armed. "Kaos Kaki Pdh Tni-Al." 2019. https://www.tokopedia.com/tokoarmed/kaos-kakipdh-tni-al-1?m id=4185271https://www.tokopedia.com/tokoarmed/kaos-kaki-pdhtni-al-1?m id=4185271, 14 Juli 2019.

Tokokitajaya. "Kaos Loreng Kapal." 2018. https://shopee.co.id/KAOS-LORENG-KAPAL-KAOSLORENG-TNI-AL-POLOS-KAOS-ARMYi.17932790.373003428https://shopee.co.id/KAOS-LORENG-KAPAL-KAOS-LORENG-TNIAL-POLOS-KAOS-ARMY-i.17932790.373003428, 14 Juli 2019.

UrbanAct. "Celana Panjang Bahan Formal Pria Slim Fit Warna Putih Urban Act." 2018. https://www.tokopedia.com/urbanact/celana-panjang-bahan-formal-pria-slim-fitwarna-putih-urban-acthttps://www.tokopedia.com/urbanact/celana-panjang-bahanformal-pria-slim-fit-warna-putih-urban-act, 14 Juli 2019.

Zakky. "Urutan Pangkat Tni Ad, Al, Au Beserta Tingkatan Dan Lambangnya." 2018. https://www.zonareferensi.com/urutan-pangkat-tni-ad-alau/https://www.zonareferensi.com/urutan-pangkat-tni-ad-al-au/, 14 Juli 2019. 